\section{Harnessing science and industry}

As the need to coordinate the work of science and industry even more closely becomes increasingly apparent to the recession-bound developed countries, Nechemia Meyers reports from Israel on the debate taking place there.

"Plans for increasing the scientific potential of Israeli industry were ready four or five years ago, but no one seemed to be in a hurry to implement them. Now, under the pressure of our worsening economic situation, people in science, government and industry are beginning to think and act much more realistically". So says Dr Eliezer Tal, Dircctor of Israel's National Council for Research and Development.

This new realism comes none too soon, for it will be required if solutions are to be found to the problems Israel now faces. First, Israeli industry must turn out more goods that can compete on the world market and, as Dr Tal points out, these will not come from the labour-intensive enterprises that were opened with such fanfare in the 1950 s and 1960s. "In view of Isracl's European-level wage structure," Tal argues, "she must concentrate on the development of high-technology products equivalent in price and-more important-in quality with those coming from the USA, western Europe and Japan."

Another problem intimately linked with this is the one of finding jobs for science graduates. The country's seven institutions of higher learning are fully staffed, and with budgets for higher education on the decline-they went down $30 \%$ in real terms during the past two years and will drop still further this year-some lecturers may even be dismissed. Only a more scientifically oriented industrial sector could, at least theoretically, absorb thousands of 'surplus' science graduates, products of local universities and immigration alike.

A controversial approach to achicving both these goals was recently offered by Richard $\mathrm{S}$. Rosenbloom, Professor of Business Administration at Harvard and, of late, Visiting Professor at the Hebrew University of Jerusalem. The primary problem, as he sees it, is not that Israel spends too little on rescarch and development. On the contrary, the country devotes a larger share of its economic resources to those ends, about $2.4 \%$ of its GNP, than any Western nation except the
USA. Even when military research and development is discounted, Israel's expenditure, $1.8 \%$ of its GNP, remains greater than the total effort of Belgium and Denmark, and about the same, per capita, as spending on civilian research in Sweden and France, although less than in the USA, the UK and the Netherlands. What disturbs Rosenbloom is that only $14.6 \%$ of Israel's civilian research and development is carried out in the business sector, as compared to $50 \%$ in Denmark and $80 \%$ in Switzerland. And the universities, where most of the other research and development is carried out, are not geared to matching technological opportunity with market needs.

What is the answer? Professor Rosenbloom has a revolutionary suggestion: the creation of an entity he calls "Israel Inc.", which would provide a countrywide framework for the innovative exploitation of technology. Israel Inc., although prepared to consider any area of research and development, would probably concentrate its attention on those where existing achievements indicate that meaningful results are most likely to be achieved, including chemicals, drugs, aircraft, industrial machinery, electronics and instrumentation.

Realising that the idea may sound "strange and impractical", Rosenbloom cites as a possible parallel the experience of General Electric (GE). GE, a highly diversified company which employs 307,000 people (as compared to the 250,000 employed by all industrial companies in Israel), has sales roughly four times as large as those of Israeli industry as a whole, and, with 700 identifiable product lines, covers almost as wide a spectrum as all manufacturing companies here put together. GE might serve as a model, Rosenbloom says, because it is not a single monolithic body, but rather a collection of quasi-independent operating units which are, at the same time, subject to certain strong influences from a central organisation.

The first step towards "Israel Inc." would be the creation, under government auspices, of a National Council for Industrial Technology, which would include the heads of all large science-oriented companics, representatives of some of the smaller companies, academics from pertinent university branches and senior government officials. Sub-groups of the council would deal with such topics as market projections, technological evaluations, manpower, funding and so on.

Next on the Rosenbloom agenda would be the establishment of an Authority for Industrial Technology, managed by the council and owned jointly by industry and government. The authority would operate its own national research and development laboratory and, at the same time, stimulate contact between research and development establishments in various sectors of the economy. Engineers and scientists employed by the authority would not only work in its laboratory, but also be sent out to other research and development centres and to universities. This system of rotation, Rosenbloom believes, would serve to break down the harriers that now hamper the flow of knowledge into industrial innovation and cut off contact between researchers and the markets in which their knowledge could be exploited.

Dr Tal agrees with Professor Rosenbloom on many points, including the advisability of merging the welter of small companies which now exist into large industrial units where serious research and development becomes possible, and the need to link industrial research with industrial policy. The Israel Government, Dr Tal declares, must decide on specific industries to promote, rather than encouraging investment in a wide range of enterprises. He would, however, shy away from the establishment of something like "Israel Inc.", which "might stifle initiative rather than promote it."

Attitudes inside industry also had to change. All large American firms, Tal points out, have a Vice President for research and development who plays a key role in policy decisions. This is far from being the case in Israel where, for example, it was only a few weeks ago that one of the country's largest companies even appointed a top level adviser on technology. Vice Presidents are still undreamed of.

A Swiss-born chemist, Rene Bloch, who heads a small but rapidly developing company engaged in work on synthetic membranes, has his own suggestion for the promotion of industrially oriented research. "To attract our most brilliant scientific minds to industry, we must give them more money and, particularly, more prestige than their university colleagues." As a symbolic first step, Dr Bloch suggests that the country's major national scientific awards-the lsrael Prize and the Rothschild Prize --should henceforth go not to "ivorytower types whose research pays off in papers", but to applied scientists whose research pays off in dollars. 